V.V. Wysochin, PhD, Assoc.Prof.,

A.S. Golovatyuk, $\mathrm{PhD}$, Assoc.Prof.

Odessa National Polytechnic University, 1 Shevchenko Ave., 65044 Odessa, Ukraine; e-mail: ostapenko.ieksu@mail.ru

\title{
STRUCTURAL FACTORS OF SOLAR SYSTEM CLUSTER GROUND COUPLED STORAGE RATIONALIZATION
}

В.В. Височин, А.С. Головатюк. Структурні фактори раціоналізації кущового грунтового акумулятора геліосистеми. Проведено чисельні дослідження нестаціонарного теплообміну в сезонному акумуляторі тепла геліосистеми 3 дев'ятьма грунтовими теплообмінниками в процесі періодичної, з добовим циклом, зарядки в літній період. Теплообмінник представлено у вигляді вертикального зонда з коаксіальним розташуванням труб. Мета: Метою роботи є визначення раціональних параметрів структури кущового грунтового акумулятора — кількості зондів у кущі, їх довжини і кроку між ними — на основі математичної моделі високої точності. Матеріали i методи: Математична модель сполученої роботи геліосистеми і грунтового акумулятора включає диференціальні рівняння, що описують умови поглинання і перетворення сонячної енергії в геліоколекторі, а також теплообмін в грунтових теплообмінниках і тривимірному масиві грунту. Результати: Показано необхідність врахування взаємного впливу розмірів геліоколекторів і грунтового теплообмінника, а також можливість підвищення ефективності акумулятора шляхом вибору раціонального кроку куща і кількості активних теплообмінників в заданій структурі. Висновки: Запропоновано рекомендації щодо організації роботи теплообмінників акумулятора. При кущовому способі організації сезонного акумулятора найбільш ефективною структурою $є$ п’ятизондова. Крок між зондами рекомендується брати таким, що дорівнює 4 м.

Ключові слова: грунтовий теплообмінник, сезонний акумулятор, зонд, геліосистема.

V.V. Wysochin, A.S. Golovatyuk. Structural factors of solar system cluster ground coupled storage rationalization. The computational investigations of unsteady heat transfer in seasonal solar heat storage system were conducted. This storage system consists of nine ground heat exchangers. The investigations were made for periodical diurnal cycle charging during summer season. The heat exchanger is presented as vertical probe with concentric tubes arrangement. Aim: The aim of the work is to optimize the cluster ground coupled storage the probes quantity in cluster, their lengths and interval - using high precision mathematical model. Materials and Methods: The mathematical model of conjugate solar system functioning and ground coupled storage involves differential equations describing the incoming and conversion of solar energy in solar collector. Also it includes the heat exchange in ground heat exchangers and three-dimensional soil mass. Results: The need of mutual influence accounting of the solar collector and the ground heat exchanger size ranges is shown. One more thing capability of effectiveness improvement of the collector based on reasonable step size selection for cluster and selection of active heat exchangers quantity in requisite construction. Conclusions: The recommendations for organization of heat exchangers of the collector work are offered. The five-probe structure is the most effective one for cluster arrangement of seasonal heat storage. The recommended interval between probes is 4 meters.

Keywords: ground heat exchangers, seasonal heat storage, probe, solar system.

Introduction. The seasonal solar heat storage system are an essential element of solar systems designed for heating. Often this objective considering, namely ground coupled storage $[1,2]$ are selected. Among them the stand vertical multiprobe (cluster) design is characterized with best performances. The heat exchanger is presented as vertical probe with concentric tubes arrangement in the wells. Sectional structure of the batteries varies by spatial distribution, probes number and heat exchangers size. These structural factors are determined by the conditions of heat storage operation in the soil, as well - as conditions of its dual operation with solar system. Significant transiency of solar systems operation does complicate practical research, due to which fact we still are in an acute need for reliable recommendations on the choice of cluster structures rational parameters, particularly, the well configuration: interval between probes and heat exchangers' length.

A typical recommendation as to the ground coupled storage structure refers to arranging a rectangular cluster at regular intervals between the probes [2...5]. Such clusters differ in the number of probes, their length and positioning distance. Structural design parameters are usually set arbitrarily. Research [4] exposes the heat exchangers number selected with respect to the area under the building foundation, and an arbitrarily chosen step of $3 \mathrm{~m}$. At study [5] the interval between probes was chosen to be $5 \mathrm{~m}$, and the source [6] reveals the $6 \mathrm{~m}$ step length. Assessment of the heat exchanger length as 
determined with the solar collectors' area, and therefore, their thermal capacity estimation, were effected only for single-probe ground storage [7]. And as to the cluster structure, none similar data found at the references. Thus, studies with unfounded-chosen storage size, are rather empirical and can never be used for practical purposes. Another scarcity of well-known studies limiting their applicability consists in the simplified processes modeling [3], in particular, mono-parametric studies of heat transfer in soil and the real solar system work environment substitution replacing the soil coupled accumulator with conventionally definable laws of heat accumulation. However, for practical purposes, it is important to establish the reliable operating parameters that implies the need to resolve tasks of the ground coupled storage structural parameters rationalization based on mathematical models of higher informational content.

The aim of this study is to optimize the cluster ground coupled storage - the probes quantity in cluster, their lengths and interval — using high precision mathematical model.

Materials and Methods. The storage cluster consists of 9 coaxial ground heat exchangers of length $h$ vertically positioned with interval between probes $S$. The problem was solved as conjugated with this one of the radiant energy absorption by solar collectors (SC) and considering the heat transfer process in the heat exchanger and the ground. The heat transfer in the ground coupled heat exchanger is described with a system of energy balance [1] differential equations: for the inner (supply) tube heat carrier; for the inner tube wall; for outer (return) tube heat carrier; for the outer wall. The soil heat transfer is described with the equation of unsteady heat conductivity in Cartesian coordinates, threedimensional problem statement.

The equations system was solved by finite difference method. Material used for heat exchanger tubes: plastic, wall thermal conductivity $\lambda_{w}=0,28 \mathrm{~W} /(\mathrm{m} \cdot \mathrm{K})$. Heat exchanger outer tubes' diameter, in accordance with [1], was assumed to be $180 \mathrm{~mm}$. Heat carrier is water. The ground heat exchanger was coupled with SC through introduction to calculated mathematical model of an equations' system describing the conditions of solar energy getting and conversion at solar collectors [1]. The solar system operation conditions were specified with Odessa region coordinates for the period that began on April $15^{\text {th }}$ (the heating season closure) and ended 6 months (180 days) elapsed. Equipment selected for study: modern flat solar collectors with the characteristics as above

$$
\frac{U}{(\tau \alpha)}=4,4 \mathrm{~W} /\left(\mathrm{m}^{2} \mathrm{~K}\right)
$$

where $U$ - heat losses coefficient;

$(\tau \alpha)$ - solar collector optic characteristics.

At the issue of mathematical model solution assessed were the heat exchanger's and ground array's temperature fields, the ground array heat content, temperature and velocity of the heat carrier circulating in the solar system as unfolds along seasonal operation. The iterative calculation of heat pumping process served to determine the total area of SC, whose thermal performance meet the criteria of maximum specified heat carrier velocity $(2 \mathrm{~m} / \mathrm{s})$ in ground heat exchangers at a fixed heat carrier temperature at the heat exchanger inlet.

Analysis of data obtained shows that the cluster probes' spacing has a significant impact on the amount of heat accumulated in the ground $Q_{\text {sum }}$ (Fig. 1). The increased step involves an increase in ground array heat content. The data represented at Fig. 1 were obtained for probes of $10 \mathrm{~m}$ length in the ground, morphologically corresponding to the clay. Similar results were obtained also for other soils.

At the end of the six-month heat accumulation cycle period under the said conditions, increasing the step from 2 to 6 meters involved the 2,7-folds growth of the peak heat $Q_{\text {peak }}$ greatest amount. This phenomenon is explained by the heat transfer intensification when increasing the temperature difference between the probe heat carrier and the ground, as the step growth reduces the soil array temperature at inter-probe space. However, the peak heat quantity dependence of the interval between probes is nonlinear. Step increased, the $Q_{\text {peak }}$ growth decreases asymptotically approaching a certain level (Fig. 2). These conditions threshold can be considered as the value $S=(5 \ldots 6) \mathrm{m}$, beyond which 
the $Q_{\text {peak }}$ function is low-sensitive to the step value. However, the step increasing leads to changes in the soil temperature, taking $t_{\mathrm{m}}$ as an indicator of temperature on the mean of interval between probes for a depth equal to half the length of the probe, we obtain (soil type: clay), the result for $180^{\text {th }}$ day of the cluster charging (step $2 \mathrm{~m}: t_{\mathrm{m}}=47^{\circ} \mathrm{C}, 4 \mathrm{~m}: t_{\mathrm{m}}=37,3^{\circ} \mathrm{C}, 6 \mathrm{~m}: t_{\mathrm{m}}=25,9^{\circ} \mathrm{C}$ ). Given the two mentioned factors, as a compromise can be selected the step of $4 \mathrm{~m}$, as corresponding to a desired storage thermal accumulation level and a sufficiently high temperature.

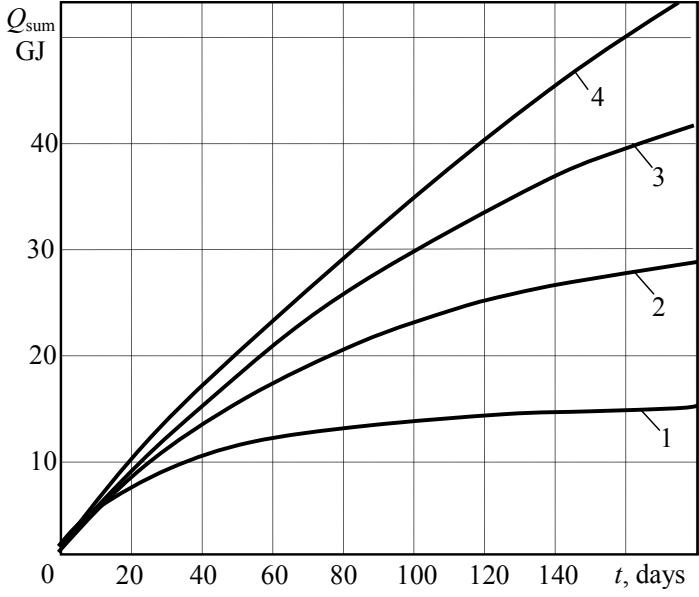

Fig. 1. Rate of changes in soil-accumulated heat amounts over 6-months heat accumulation period considering varied interval between probes: $1-2 \mathrm{~m}$; $2-3 m ; 3-4 m ; 4-6 m$

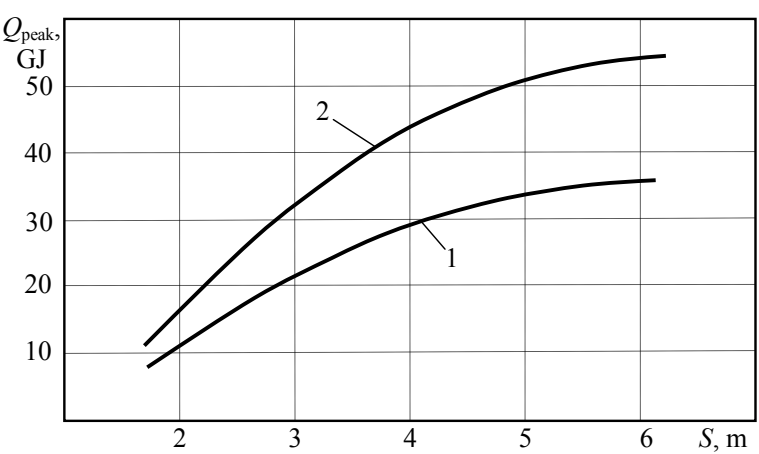

Fig. 2. Dependence between the heat peak amounts and the cluster probes step at different soils:

$$
1 \text {-sand; } 2 \text { - clay }
$$

Another factor influencing the efficiency of heat accumulation is the number of active probes in the cluster (Fig.3). The design scheme was formed by sequentially excluding the heat exchangers making part to 9-probes cluster. Basic diagram represents case of all heat exchangers operative, this one with five active coils was obtained upon disconnecting the lateral four probes lying on the crosssectional diagonal; the diagram of one heat exchanger was obtained upon disconnecting the lateral eight coils. Interval between probes is $4 \mathrm{~m}$. The data obtained shows that a single probe is significantly inferior to the cluster storage (Fig. 3). However, a further increase in the number of cluster heat exchangers has little effect on the storage thermal characteristics improvement. This is due to the restructuring of the temperature field thus reducing the temperature gradient that affects the heat transfer between probes and the ground. Thus, despite an increase in the cluster heat transfer area, separate heat exchangers at 9-elements cluster are less productive that at 5 -elements one.

More informative results can be obtained using the criterion of the solar collectors' total area ratio to peak heat quantity accumulated in the soil $A_{\text {sum }} / Q_{\text {peak }}$. This figure represents a specific SC area required for charging the ground coupled storage up to a predetermined limit. Analysis of this parameter dependence on the number of cluster probes shows that an increase in the probes number is concurrent to the $A_{\text {sum }} / Q_{\text {peak }}$ increase (Fig. 4). The dependency growth rate is related to the interval between probes. The highest growth rate is observed for interval of $2 \mathrm{~m}$, while the interval of 4 to $6 \mathrm{~m}$ does insignificantly influence this rate. The cluster of five probes with interval of $4 \mathrm{~m}$, previously defined as a rational one, has the least necessary specific area of solar collectors.

Fig. 5 shows the dependence of probe length $h$ from the related solar collectors area $A$ required for one heat exchanger operation at sectional structure. The data suggests that an increased SC area requires increasing the probe length. The dependence is close to linear, and its parameter is the soil thermal conductivity $a_{s}$. With the growth of $a_{s}$, the degree of SC area influence onto probe length decreases. 


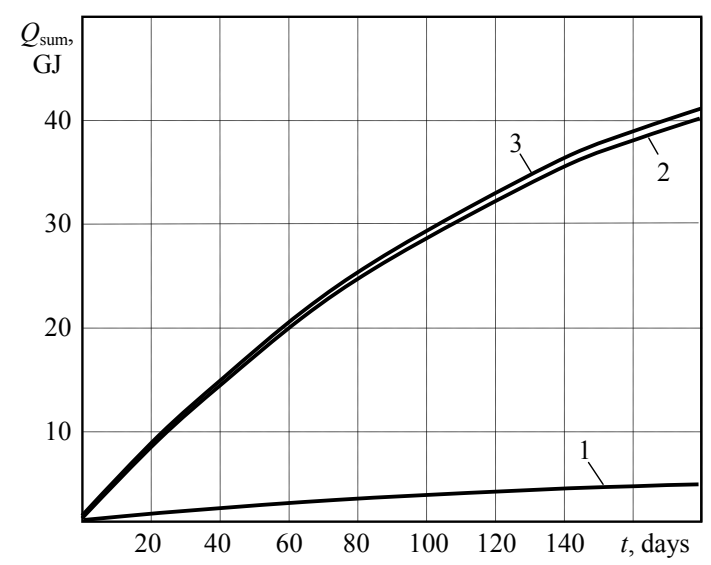

Fig. 3. Excessive heat content of the clay soil array over 6-months heat accumulation period, considering different probes number at the cluster: $1-1$ probe; 2 - 5 probes; 3 - 9 probes

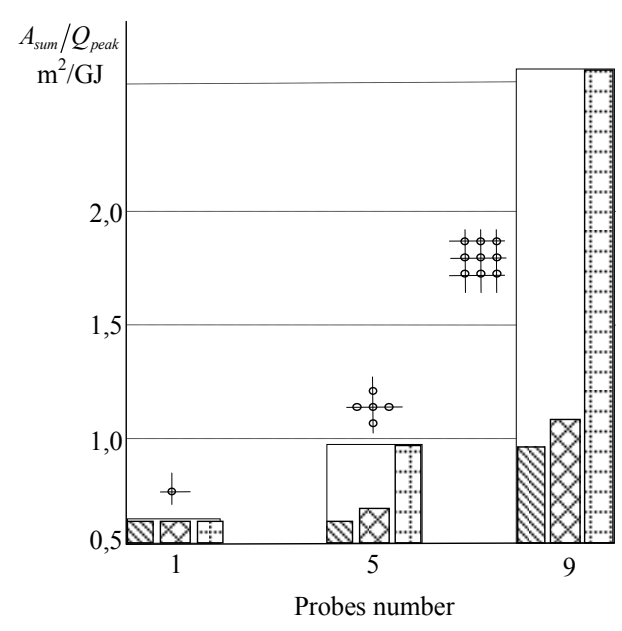

Fig. 4. Solar collectors' relative area dependence onto the cluster probes number. Interval between probes,

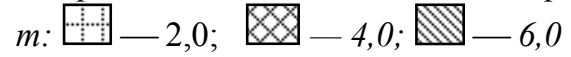

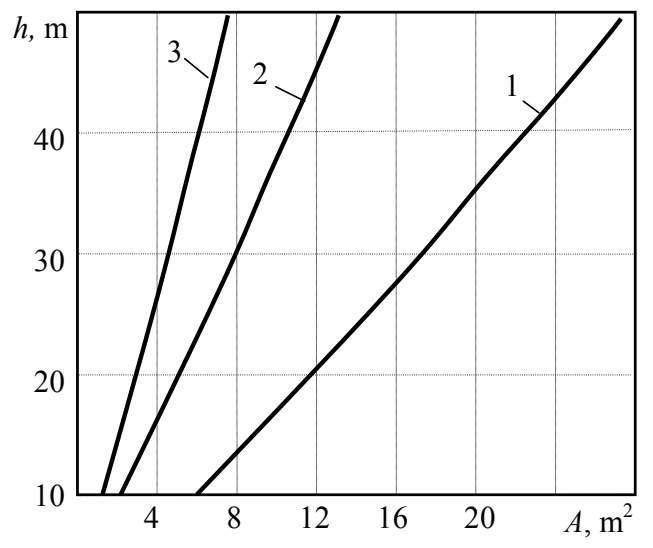

Fig. 5. Requires probe length dependence onto the solar collectors' area. Soil thermal conductivity $a_{s}, \times 10^{7}$ :

$$
1-9,61 ; 2-5,5 ; 3-2,78
$$

Results. A summary of the researched data gives grounds to elaborate recommendations on the organization of the solar system cluster ground coupled storage structure. The interval between probes preferably should be chosen equal to $4 \mathrm{~m}$ as corresponding to good level of storage thermal accumulation at sufficiently high temperature. A more informed choices as to the arrangement step should be based on thermo-physical properties of the soil, as well as modes of solar system when charging and discharging the ground storage, which question requires an additional research. Use of 9-probes cluster system is assessed as inappropriate by factor of ground array thermal accumulation; the optimal and rational structure is a 5-probes one.

The obtained data for determining the probe length at solar systems with different values of the absorbing surfaces' area and for different soils can be approximated with an error of no more than $3 \%$ by the following expression:

$$
h=5,1 \cdot A \cdot \exp \left(-1,8 \cdot 10^{6} \cdot a_{s}\right)+1,133-\left(0,365-1,92 \cdot 10^{6} \cdot a_{s}\right)^{2} .
$$

The generalizing expression is obtained for solar systems with flat SC within the definition area: $\frac{U}{(\tau \alpha)}=4,4 \mathrm{~W} /\left(\mathrm{m}^{2} \mathrm{~K}\right)$; the SC area calculated per one probe $A=(2,9 \ldots 28) \mathrm{m}^{2}$; for soils with thermal conductivity coefficients $a_{s}=(2,78 \ldots 9,61) \cdot 10^{-7} \mathrm{~m}^{2} / \mathrm{s}$.

Conclusions. The recommendations for organization of heat exchangers of the collector work are offered. The five-probe structure is the most effective one for cluster arrangement of seasonal heat storage. The recommended interval between probes is $4 \mathrm{~m}$. A generalized dependence suggested, allows determining the solar probe length at the cluster structure for the condition of rational operation modes, depending on the solar collectors' area and thermal properties of the soil. 


\section{Література}

1. Высочин, В.В. Роль грунтового теплообменника в сглаживании неравномерности работы гелиосистемы / В.В. Высочин, А.Ю. Громовой // Пр. Одес. політехн. ун-ту. — 2013. — Вип. 2(41). C. $148-152$.

2. Накорчевский, А.И. Оптимальная конструкция грунтовых теплообменников А.И. Накорчевский, Б.И. Басок // Пром. теплотехника. - 2005. - Т. 27, № 6. - С. $27-31$.

3. Височин, В.В. Умови цілодобової зарядки кущового грунтового акумулятора геліосистеми / В.В. Височин, С.І. Кожухар // Пр. Одес. політехн. ун-ту. — 2013. — Вип. 2(46). — С. $92-96$.

4. Экспериментальные исследования рабочих режимов грунтового аккумулятора в системе теплоснабжения дома / А.В. Трофименко, А.А. Дмитренко, Д.П. Лапко, М.А. Назаренко // Пром. теплотехника. - 2010. - Т. 32, № 5. - С. $67-71$.

5. Накорчевский, А.И. Проблемы грунтового аккумулирования теплоты и методы их решения / А.И. Накорчевский, Б.И. Басок, Т.Г. Беляева // Пром. теплотехника. — 2003. - Т. 25, № 3. С. $42-50$.

6. Накорчевский, А.И. Рациональные решения в теплогенерирующей системе «грунтовый массив тепловой насос» / А.И. Накорчевский // Пром. теплотехника. — 2007. — Т. 29, № 4. — С. $77-82$.

7. Высочин, В.В. Влияние размеров грунтового теплообменника на сопряженные режимы работы с гелиосистемой / В.В. Высочин, В.И. Моцный // Пр. Одес. політехн. ун-ту. — 2014. - Вип. 1(43). - C. $137-141$.

\section{References}

1. Wysochin, V.V., \& Gromovoy, A.J. (2013). The role of the ground heat exchanger to leveling irregularity of solar plant system operation. Odes'kyi Politechnichnyi Universytet. Pratsi, 2, 148-152.

2. Nakorchevsky, A.I., \& Basok, B.I. (2005). Optimal design of ground heat exchangers. Industrial Heat Engineering, 27(6), 27-31.

3. Wysochin, V.V., \& Kozhukhar, Ye.I. (2015). The conditions of twenty-four-hour charging of the group ground accumulator of solar plant system. Odes'kyi Politechnichnyi Universytet. Pratsi, 2, 92-96. DOI:10.15276/opu.2.46.2015.17

4. Trofimenko, A., Dmitrenko, A., Lapko, D., \& Nazarenko, M. (2010). Experimental researches of operating conditions of the soil accumulator in system of the heat supply of the house. Industrial Heat Engineering, 32(5), 67-71.

5. Nakorchevsky, A.I., Basok, A.I., \& Belyaeva, T.G. (2003). Problems of soil heat accumulation and methods of their solution. Industrial Heat Engineering, 25(3), 42-50.

6. Nakorchevsky, A. (2007). Rational decision in a heat generating system "soil massif - heat pump". Industrial Heat Engineering, 29(4), 77-82.

7. Wysochin, V.V., \& Motsny, V.I. (2014). Effect of the ground heat exchanger dimensions on the heliosystem operation with coupled modes. Odes'kyi Politechnichnyi Universytet. Pratsi, 1, 137-141. DOI:10.15276/opu.1.43.2014.23 